\title{
New record of Cuspidaria patagonica Smith, 1885 (Bivalvia: Cuspidariidae) in northern Chile
}

\author{
Nuevo registro de Cuspidaria patagonica Smith, 1885 (Bivalvia: Cuspidariidae) en el \\ norte de Chile
}

\author{
Juan Francisco Araya ${ }^{1 *} \&$ Ricardo Catalán ${ }^{2}$ \\ ${ }^{1}$ Departamento de Geología, Universidad de Atacama, Copayapu 485, Copiapó, Region of Atacama, Chile. \\ orcid.org/0000-0002-4087-9641 \\ urn:Isid:zoobank.org:author:443B4F42-FB13-42A6-B92B-1B0F835698A9 \\ ${ }^{2}$ Ministerio del Medio Ambiente, Portales 830, Copiapó, Región de Atacama, Chile \\ *E-mail: jfaraya@u.uchile.cl
}

Deep water mollusks have been sparsely studied in Chile and, apart from some classic works (e. g. Smith 1885; Dall 1889, 1890, among others) and studies done mostly in central-southern Chile (Sellanes \& Krylova 2005, Holmes et al. 2006, Fraussen \& Sellanes 2008, among others), only a few recent works have reviewed species from the northern areas of the country (Bernard 1988, Guzmán et al. 1998, Véliz \& Vásquez 2000, Pacheco \& Laudien 2008, Araya 2013). Among the deep-water bivalves, genus Cuspidaria Nardo, 1840 encompasses several small species with nearly equivalve but markedly inequilateral smooth shells, with the posterior end rostrate to spoutlike and a hinge with one posterior lateral tooth (Keen 1971). This genus is represented in Chile by three species, all of them found in deep waters: Cuspidaria infelix Thiele, 1912 and Cuspidaria tenella Smith, 1907, both species found in Antarctic waters and in southern Patagonia (C. infelix) and Cuspidaria patagonica (Smith, 1885), which has been previously recorded in the Strait of Magellan (Smith 1885, Valdovinos 1999).

As part of ongoing studies reviewing the macroinvertebrates from the bycatch of deep-water fisheries off northern Chile (Araya 2013, 2016, Reiswig \& Araya 2014, Araya et al. 2016b), we present here the first confirmed record in northern Chile of Cuspidaria patagonica (Smith, 1885), extending its previous distribution in the country in more than 2570 $\mathrm{km}$ to the north. This record is based on two specimens of $C$. patagonica collected in shrimp trawls along the continental

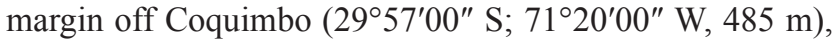
Región de Coquimbo, northern Chile. A voucher specimen (MPCCL 15316) is deposited at the Museo Paleontológico de Caldera (MPCCL), in Caldera, Chile.
Family CuspidariIdae Dall, 1886

Genus Cuspidaria Nardo, 1840

TyPe SPECIES: Cuspidaria typus Nardo, 1840; type by original designation.

Cuspidaria patagonica (Smith, 1885)

(Fig. 1a-e)

Neaera patagonica Smith, 1885: 39, pl. VII, figs. 5, 5a-b. Cuspidaria patagonica Dall, 1889: 443. Dall, 1890: 279. Keen, 1971: 300. Bernard, 1983: 66.

DESCRIPTION OF EXAMINED SPECIMENS: Shell large (42 $\mathrm{mm}$ in largest dimension), inflated, rostrate, equivalve, subequilateral, whitish, covered with a yellowish-brown periostracum, paler toward the middle of the disk; surface sculptured by minute commarginal lines, more marked toward the borders; rostrum long and rather narrow, a little recurved and gaping at its extremity; beaks inflated, opisthogyrate; long and smooth escutcheon, lunule absent; interior of shell white, porcellanous; pallial sinus absent.

DistriBution: This species was originally described from off the West mouth of the Magellan Straits in a depth of 675 $\mathrm{m}$ (Smith 1885) and was further recorded from the same areas in southern Chile and from off St. Kitts, West Indies, off Manta, Ecuador, in the Gulf of Panama and up to Lower California (Dall 1889, 1890, 1908). The distribution of this species in Chile was assumed to be continuous from $15^{\circ}$ to $55^{\circ} \mathrm{S}$, by considering the type location at the Magellan strait and the records from Ecuador by Valdovinos (1999); however, the present record is the first confirmed report of this species in northern Chile. 
This rather large Cuspidaria species is easily distinguished from other bivalves by its long, distinctly defined and constricted rostrum. The specimens herein examined show little difference with the holotype of the species (USNM96241), differing only in having a slightly narrower rostrum probably due to the larger size of the northern Chilean specimens (see for example Fig. 1e). The lack of records for this deep water bivalve (and for several other deep water macroinvertebrates) probably arises from a lack of sampling surveys in deep water rather than representing a true absence of these organisms in the area. This has been exemplified by several recent works, which have revealed new records and new species of marine invertebrates from northern Chile (e.g. Araya \& Aliaga 2016, Araya \& Araya 2015, Araya et al. 2016a, Labrín et al. 2015) and thereby, further sampling in similar areas may reveal the presence of other unrecorded organisms.

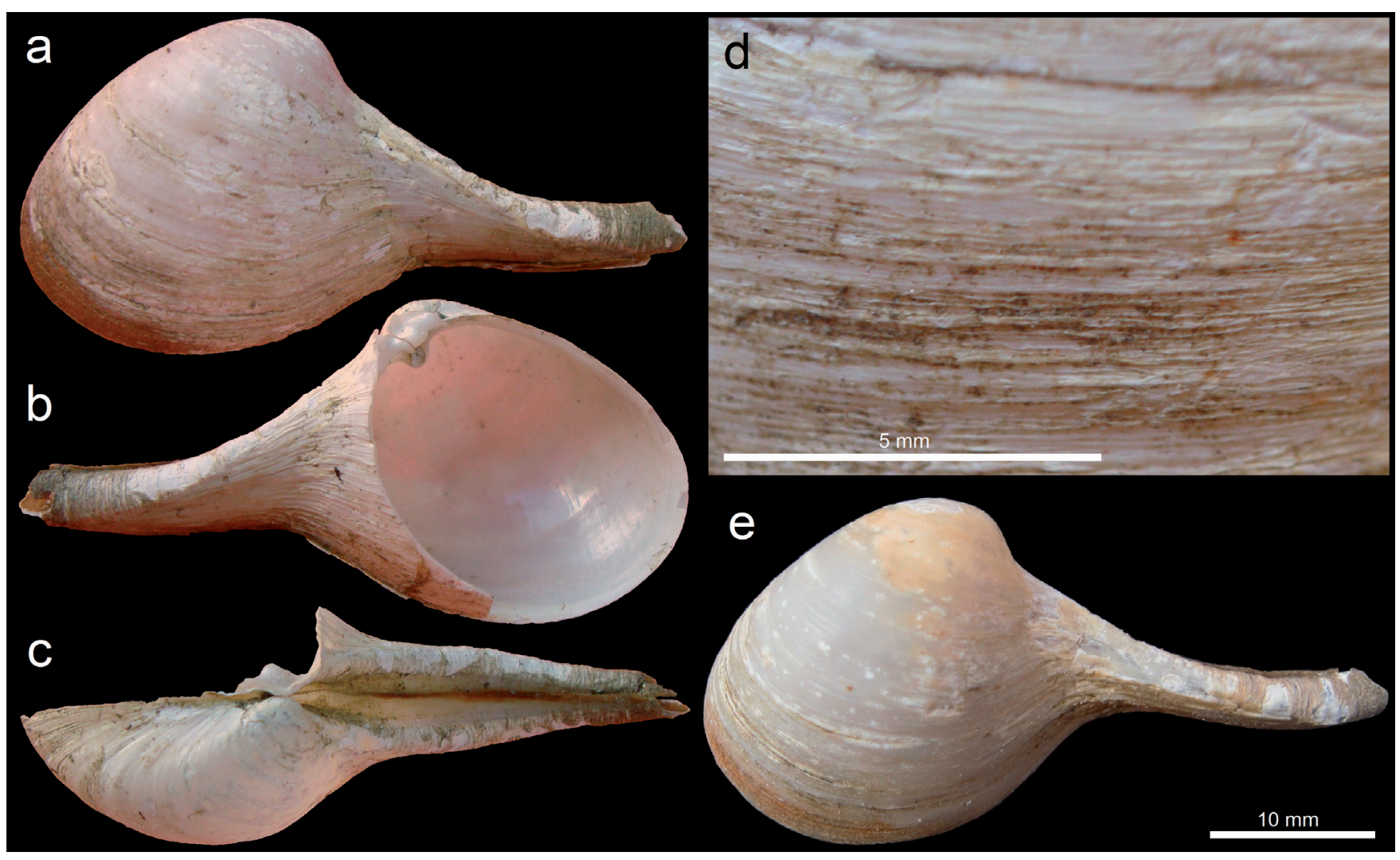

Figure 1. Cuspidaria patagonica Smith, 1885, off Coquimbo, Chile, $485 \mathrm{~m}$ depth (MPCCL 15316); a: exterior of left valve; b: interior of left valve (broken); c: posterior view; d: detail of commarginal sculpture; e: exterior of left valve of second specimen examined.

Figura 1. Cuspidaria patagonica Smith, 1885, fuera de Coquimbo, Chile, $485 \mathrm{~m}$ de profundidad (MPCCL 15316); a: exterior de valva izquierda; b: interior de valva izquierda (quebrada); c: vista posterior; d: detalle de escultura conmarginal; e: exterior de valva izquierda del segundo ejemplar examinado.

\section{BIBLIOGRAPHY}

ArAYA, J.F. 2013. A new species of Aeneator Finlay, 1926 (Mollusca, Gastropoda, Buccinidae) from northern Chile, with comments on the genus and a key to the Chilean species. ZooKeys 257:89-101

AraYA, J.F. 2016. New records of deep-sea sea spiders (Chelicerata: Pycnogonida) in the southeastern Pacific. Marine Biodiversity 46(3):725-729.

Araya, J.F. \& Aliaga, J.A. 2016. The northernmost record of Tytthosoceros inca Baeza, Véliz, Pardo, Lohrmann and
Guisado 1997 (Plathyhelminthes: Pseudocerotidae) in Chile. Marine Biodiversity 46(2):335-336.

Araya, J.F \& ARaYA, M.E. 2015. The shallow-water chitons (Mollusca, Polyplacophora) of Caldera, Region of Atacama, northern Chile. Zoosystematics and Evolution 91: 45-58.

Araya, J.F., Aliaga, J.A. \& Araya, M.E. 2016. On the distribution of Physalia physalis (Hydrozoa: Physaliidae) in Chile. Marine Biodiversity 46(3):731-735.

Araya, J.F., Aliaga, J.A. \& Araya, M.E. 2016. First record of Lillipathes ritamariae Opresko and Breedy, 2010 
(Cnidaria: Antipatharia) in the southeastern Pacific Ocean. Marine Biodiversity http://dx.doi.org/10.1007/s12526016-0591-1.

Bernard, F. R. 1983. Catalogue of the living Bivalvia of the Eastern Pacific Ocean: Bering Strait to Cape Horn. Canadian Special Publication of Fisheries and Aquatic Sciences 61:1-102.

Bernard, F.R. (1988) Five New Species of the Family Limidae (Bivalvia) from the Eastern Pacific Ocean. Venus 47(4):225-232.

DALL, W.H. 1889. Reports on the results of dredging, under the supervision of Alexander Agassiz, in the Gulf of Mexico (1877-1878) and in the Caribbean Sea (1879-80), by the U. S. Coast Survey Steamer "Blake", Lieut.-Commander C. D. Sigsbee, U. S. N., and Commander J. R. Bartlett, U. S. N., commanding. XXIX.- Report on the Mollusca. Addenda and Corrigenda to Part I., 1886. Bulletin of the Museum of Comparative Zoology 18:433-452.

DALL, W.H. 1890. Scientific results of explorations by steamer Albatross No. VII. Preliminary reporto $n$ the collection of mollusca and brachiopoda obtained in 1887-'88. Proceedings of the United States National Museum 12:219-362.

Fraussen, K. \& Sellanes, J. 2008. Three new buccinid species (Gastropoda: Neogastropoda) from Chilean deep-water, including one from a methane seep. The Veliger 50:97106.

Guzmán, N., SaÁ, S. \& Ortlieb, L. 1998. Catálogo descriptivo de los moluscos litorales (Gastropoda y Pelecypoda) de la zona de Antofagasta $23^{\circ} \mathrm{S}$ (Chile). Estudios Oceanológicos 17:17-86.
Holmes, A.M., Oliver, P.G. \& Sellanes, J. 2006. A new species of Lucinoma (Bivalvia: Lucinoidea) from a methane gas seep off the southwest coast of Chile. Journal of Conchology 38(6):673-682.

KeEn, A.M. 1971. Sea shells of tropical West America: marine mollusks from Baja California to Peru. Stanford University Press, Stanford, USA. 1080 pp.

Labrín, M., Guzmán, G. \& Sielfeld, W. 2015. Pterópodos thecosomados en el Pacífico suroriental frente a Caldera, Chile (Mollusca, Opistobranchiata: Euthecostomata y Pseudothecostomata). Latin American Journal of Aquatic Research 43(1):71-79.

Pacheco, A. \& Laudien, J. 2008. Dendropoma mejillonensis sp. nov. a new species of Vermetid (Mollusca: Caenogastropoda,) from Northern Chile. The Veliger 50(3):219-224.

Reiswig, H. \& Araya, J.F. 2014. A review of the Hexactinellida (Porifera) of Chile, with the first record of Caulophacus Schulze, 1885 (Lyssacinosida: Rossellidae) from the Southeastern Pacific Ocean. Zootaxa 3889(3):414-428.

Sellanes, J. \& Krylova, E. 2005. A new species of Calyptogena (Bivalvia, Vesicomyidae) from a recently discovered methane seepage area off Concepción Bay, Chile (368S). Journal of the Marine Biological Association of the United Kingdom 85: 969-976.

SмIтH, E.A. 1885. Report on the Lamellibranchiata collected by H.M.S. 'Challenger', during the years 1873-1876. Challenger Reports, Zoology 13:1-341.

Valdovinos, C. 1999. Biodiversidad de moluscos chilenos: base de datos taxonómica y distribucional. Gayana 63:111-164.

VÉliz, D. \& VÁsqueZ, J.A. 2000. La Familia Trochidae (Mollusca: Gastropoda) en el norte de Chile: consideraciones ecológicas y taxonómicas. Revista Chilena de Historia Natural 73(4):757-769.

Recibido: 15.03 .16

Aceptado: 04.11.16 